\title{
THE ROLE OF INFLAMMATION IN THE UTERINE WEIGHT INCREASE CAUSED BY AN IUD
}

\author{
EARL PARR \\ The Rockefeller University, New York City, New York, U.S.A.
}

(Received 20th February 1968)

\begin{abstract}
Summary. Foreign bodies in the uteri of germ-free and conventional rats caused a weight increase only in those portions of the uterus where there was an inflammatory reaction. In oestrogen-deprived, conventional animals, uterine inflammation prevented involution and the disappearance of nucleoli from the endometrium. It appears that inflammation is responsible for the weight increase in uteri containing foreign bodies. It is suggested that inflammation may also be responsible for the luteolytic effect of uterine foreign bodies.
\end{abstract}

\section{INTRODUCTION}

An IUD in one horn of the uterus in rats (Parr \& Segal, 1966), rabbits (Ledger \& Bickley, 1966) and goats (Janakiraman, Shykla, Gadgil \& Buch, 1966) caused an increase in the weight of that horn when compared to the control horn. An IUD probably also increased the weight of the human uterus (Dickinson \& Smith, 1913; Grafenberg, 1931; Israel \& Davis, 1966). It has been suggested that the basis of the anti-fertility effect of a uterine foreign body is chronic inflammation (Parr, Schaedler \& Hirsch, 1967). Some observations on the effects of a foreign body in germ-free rats, and in oestrogen-deprived conventional rats, suggest that inflammation may also be the cause of the uterine weight increase.

\section{PROCEDURES}

Female germ-free rats received silk or stainless steel sutures, approximately $1 \mathrm{~cm}$ long, in one horn. The animals were killed in di-oestrus or on Day 8 of pregnancy. The details of the handling of the germ-free rats have been published (Parr et al., 1967). Conventional Holtzmann female rats were ovariectomized and adrenalectomized bilaterally to provide oestrogen-deprived animals and, at the same time, each received a 3-0 silk suture in one uterine horn. The animals were killed 3 weeks after the operation; uterine horns were weighed and then processed for histology.

\section{RESULTS}

In germ-free rats, the most obvious aspect of the appearance of uterine horns containing foreign bodies was that the uterus was enlarged at the position of 
the foreign body but not elsewhere. Plate 1, Fig. 1 shows this localized uterine growth. It has been shown that an inflammatory reaction in germ-free uterine horns containing foreign bodies was strictly limited to the tissue directly in contact with the foreign body (Parr et al., 1967). In conventional rats we have observed that the uterine weight increase was distributed along the entire length of the horn containing the foreign body; the increase was not restricted to the short segment in contact with the foreign body. This distribution of the uterine weight increase in conventional rats has also been noted by Craig (1967). Greenwald (1965) first observed that an inflammatory reaction occurred along the entire length of rat uterine horns containing foreign bodies; we confirmed this observation (Parr et al., 1967) and found that such horns were infected. These observations on germ-free and conventional rats establish that the uterine weight increase occurs in the inflamed regions and not elsewhere.

Oestrogen was not necessary for the foreign body-induced uterine weight increase, since a silk suture caused an increase in the weight of the uterus in

TABLE 1

WET WEIGHT OF UTERINE HORNS

FROM OVARIEGTOMIZED-ADRENALEGTOMIZED RATS*

\begin{tabular}{c|c}
\hline $\begin{array}{c}\text { Horns containing } \\
\text { foreign body } \\
(\mathrm{mg})\end{array}$ & $\begin{array}{c}\text { Control horns } \\
(\mathrm{mg})\end{array}$ \\
\hline $73 \pm 4$ & $38 \pm 2$ \\
\hline
\end{tabular}

Average wet weight increase $=92 \%$.

Average dry weight increase $=79 \%$.

* Values listed are means and stan-

dard errors from fifteen measurements.

ovariectomized and adrenalectomized rats (Table 1). This result does not support suggestions that the weight increase may be due to increased sensitivity to or binding of oestrogen in the horn containing the foreign body (Pincus, 1964; Kar, Kamboj, Goswami \& Chowdhury, 1964). In the oestrogen-deprived female rats, the control uterine horns involuted and nucleoli disappeared from the nuclei of epithelial and stromal cells within 3 weeks (Pl. 2, Fig. 2). In the horns containing foreign bodies, however, nucleoli did not disappear from the inflamed regions (PI. 2, Fig. 3). Nucleoli were present throughout the endometrium, and those in epithelial cells were often extremely large. Thus a foreign body prevented the disappearance of uterine nucleoli and partially prevented uterine involution. Throughout the non-inflamed regions of the oestrogen-deprived uterus containing a foreign body, nucleoli disappeared as usual. In two germ-free rats that remained in di-oestrus for over 3 weeks, there were no nucleoli in the non-inflamed regions and the horns were involuted; but there were prominent nucleoli in the inflamed segments containing the foreign bodies. Thus the persistence of nucleoli in the oestrogen-deprived rat uterus seems to depend on uterine inflammation. 
PLATE 1

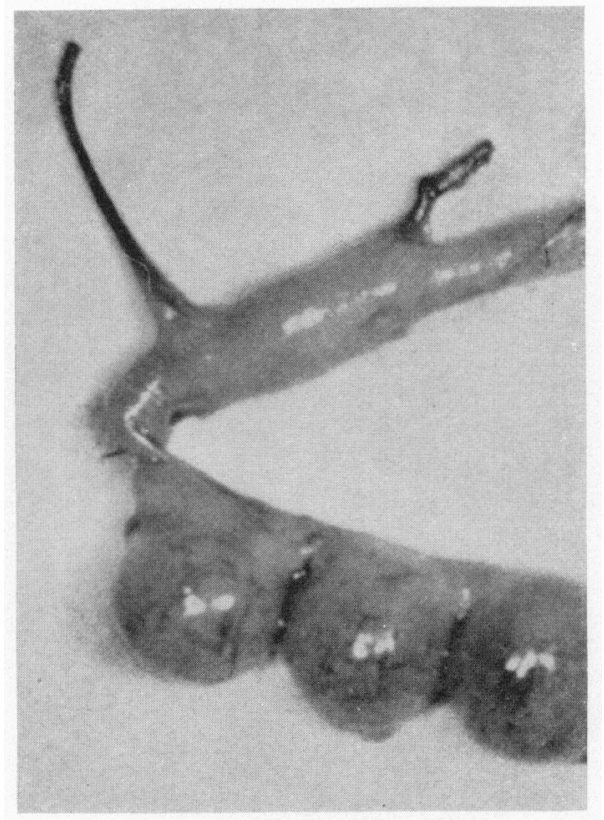

Fig. 1. Portion of a germ-free rat uterus on Day 8 of gestation showing the localized growth of the uterus around the foreign body. The foreign body has been in situ 48 days. $\times 3$.

(Facing p. 222) 
PLATE 2

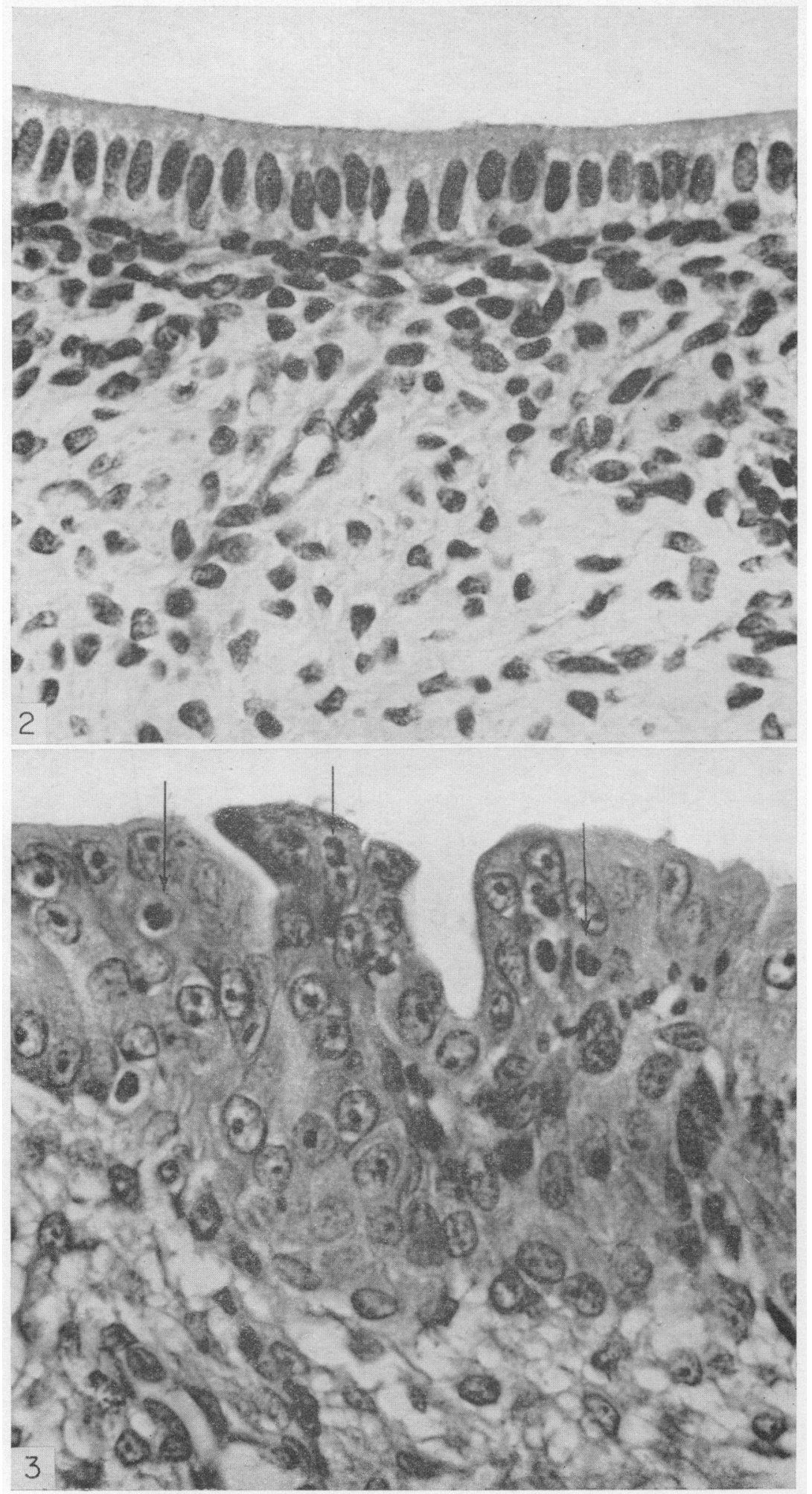




\section{DISCUSSION}

Inflammation has long been known to result in the accumulation and multiplication of connective tissue cells, usually designated as fibroblasts, concomitant with the deposition of collagen. The extent and duration of both of these processes seems to be determined by the degree of injury, or subsequent leucocytic exudation, or both (Dumont, 1965). These responses are fundamental to the repair of injured connective tissue. It should be no surprise, then, that the inflammation provoked by an IUD causes an increase in the wet and dry weights of the uterus. Consistent with this interpretation is the finding of increased acid mucopolysaccharides (hexosamine) in cow and sheep uteri containing a foreign body (Cooper \& Hawk, 1967, 1968).

Nucleoli are generally believed to reflect cellular synthetic activity, and uterine nucleoli are no exception. Oestrogens (Wilson, 1963) and progestins (Hooker \& Forbes, 1947) cause nucleoli to appear in the uteri of ovariectomized animals, and these hormones are known to stimulate the synthesis of RNA and protein in the uterus. The uterine nucleoli that are associated with inflammation may thus be an indication of the cellular activity involved in the proliferation of fibroblasts and the deposition of ground substance. A relation between these responses and the nucleolus has not been reported previously. Its easy detection here probably depended on the complete absence of nucleoli in the uteri of oestrogen-deprived animals unless inflammation was present. In most tissues there is no experimental technique that completely eliminates nucleoli, and quantitative changes in the size or number of nucleoli during inflammation would be likely to go unnoticed; indeed, in normally cycling females the nucleolar differences noted above were not readily apparent.

The only observation which cautions that the uterine weight increase caused by an IUD may not simply be a consequence of inflammation is the failure of cortisol, an anti-inflammatory steroid, to suppress the weight increase (Parr \& Segal, 1966). In rats which had an IUD in one horn and a cotton ball under the skin, cortisol suppressed a weight increase in the cotton balls but did not diminish the uterine weight increase. In general, however, the inflammatory diseases which cortisol and related compounds have been found to influence favourably are those of an allergic nature or those resulting from some form of trauma, but not those inflammations that result from an infective process. Indeed, in rats, the administration of cortisol usually makes bacterial infections worse (Florey, 1962). Since the rat uterus containing a foreign body has been shown to be

EXPLANATION OF PLATE 2

Fig. 2. Section of the control uterine horn from a rat 3 weeks after ovariectomy, adrenalectomy and the insertion of a silk suture foreign body into the opposite horn. There are no longer any nucleoli in the cells of the endometrium and no leucocytes are present. The cytoplasm of the epithelial cells is not basophilic. The sections in Figs. 2 and 3 were fixed in Bouin's solution and stained with haematoxylin and eosin. $\times 610$.

Frg. 3. Section of the horn containing the foreign body in the same rat as that of Fig. 2. Nucleoli are present in the epithelial cells and stromal cells, and several polymorphonuclear leucocytes can be identified (arrows). Metaplasia of the epithelial layer appears to have been developing in this horn. Both squamous and keratinizing metaplasia are occasionally observed in rat uterine horns containing a silk suture, and metaplasia is also found in other chronically inflamed tissues. The cytoplasm of the epithelial cells is distinctly more basophilic than that in the epithelial cells of control horns. $\times 610$. 
infected (Parr et al., 1967), it should not be expected that cortisol treatment would decrease the uterine inflammation.

The observations discussed above suggest that the uterine weight increase caused by a foreign body is due to chronic inflammation. We would also like to discuss briefly some observations by other workers which suggest that inflammation may be the cause of the luteolysis induced by uterine foreign bodies. An IUD shortened the duration of the oestrous cycle in cows (Yamauchi \& Nakahara, 1958; Hansel \& Wagner, 1960; Chatterjee \& Luktuke, 1961; Hawk, Conley, Brinsfield \& Righter, 1964; Ginther, Woody, Janakiraman \& Casida, 1966), sheep (Nalbandov, Moore \& Norton, 1955; Inskeep, Oloufa, Howland, Pope \& Casida, 1962; Anderson, Bowerman \& Melampy, 1963a; Ginther, Pope \& Casida, 1966) and guinea-pigs (Anderson, Bowerman \& Melampy, 1963b; Bland \& Donovan, 1966; Ginther, Mahajan \& Gasida, 1966). An IUD produced chronic inflammation in cows (Hawk et al., 1964; Ginther et al., 1966) and sheep (Ginther et al., 1966; Hawk, 1967).

Although the luteolysis caused by uterine foreign bodies has usually been thought to depend on stretching of the uterus, it is quite likely that uterine inflammation can also shorten the oestrous cycle. It has been demonstrated, for example, that the injection into the bovine uterus, early in oestrus, of excessively large quantities of spermatozoa or of dead bacteria or other non-specific irritants, caused the next oestrus to appear early (Hansel, 1966; Yamauchi, Nakahara, Kaneda \& Inui, 1967). Subsequent oestrous cycles were normal in length, as would be expected from a short-lived inflammation. In sheep, the injection of bacteria into the uterus on the 2nd day of oestrus caused luteolysis (Brinsfield \& Hawk, 1967). In cows (Yamauchi et al., 1967) and sheep (Brinsfield \& Hawk, 1967), the injection of foreign matter was followed by a uterine inflammatory reaction. Studies on the uterine inflammatory response to irritants, including dead bacteria and dead spermatozoa, in other species also, leave little doubt that these substances would produce uterine inflammation in cows and sheep (Austin, 1957; Broome, Lamming \& Smith, 1959; Brinsfield, Hawk \& Leffel, 1963; Marcus, 1965). It is unlikely that the injections of foreign matter significantly distend the uterus for any extended period.

Thus it appears that in some species luteolysis can be caused by an acute uterine inflammatory reaction beginning early in oestrus without significant uterine distension. This suggests that the luteolysis caused by a uterine foreign body in sheep, cows and guinea-pigs is due to the chronic inflammatory response to the foreign body rather than to uterine distension. The details of the process are entirely obscure, but it is well established that the uterus exerts a controlling influence over the corpus luteum in cows, sheep and guinea-pigs (Anderson et al., 1963; Bland \& Donovan, 1966). This uterine influence is luteolytic, for the surgical removal of the uterus allows a corpus luteum to persist indefinitely. Future research may show that uterine inflammation, by producing an increase in the number and synthetic activity of uterine cells, can enhance the secretion of a uterine luteolytic substance (Donovan, 1967).

ACKNOWLEDGMENT

Supported in part by Public Health Service Grants E-01831 and AI-0567-04. 


\section{REFERENCES}

Anderson, L. L., Bowerman, A. M. \& Melampy, R. M. (1963a) Neuro-utero-ovarian relationships. In: Advances in Neuroendocrinology, p. 357. Ed. A. V. Nalbandov. University of Illinois Press, Urbana.

Anderson, L. L., Bowerman, A. M. \& Melampy, R. M. (1963b) Neuro-utero-ovarian relationships. In: Advances in Neuroendocrinology, p. 359. Ed. A. V. Nalbandov. University of Illinois Press, Urbana.

Austin, G. R. (1957) Fate of spermatozoa in the uterus of mouse and rat. F. Endocr. 14, 335.

Bland, K. P. \& Donovan, B. T. (1966) The uterus and control of ovarian function. Adv. reprod. Physiol. 1,179 .

Brinsfield, T. H. \& HaWk, H. W. (1967) Luteolytic effect of induced uterine infection in ewes. $\mathcal{F}$. Anim. Sci. 26, 941.

Brinsfield, T. H., HaWk, H. W. \& Leffel, E. C. (1963) Control by ovarian hormones of the inflammatory response in the sheep uterus. F. Reprod. Fert. 6, 79.

Broome, A. W. J., Lamming, G. E. \& Smith, W. (1959) Studies on the relationship between ovarian hormones and uterine infection. F. Endocr. 19, 274.

Chatterjee, S. N. \& Luktuke, S. N. (1961) Studies on induction of sterility in scrub cows by intrauterine introduction of spring pessaries. F. Reprod. Fert. 2, 196.

Cooper, B. S. \& Hawk, H. W. (1967) Endometrial mucopolysaccharides in the ewe. 7. Anim. Sci. 26, 942.

CoOper, B. S. \& HAWK, H. W. (1968) Effect of intra-uterine devices on endometrial mucopolysaccharides in the cow. Fert. Steril. 19, 310.

CRAIG, J. M. (1967) The effect of intrauterine string on the rat uterus. Fert. Steril. 18, 466.

Dickinson, R. L. \& Smrth, W. S. (1913) The treatment of anteflexion, defective function and sterility by glass or silver stems. Am. F. Obstet. Gynec. 68, 686.

Donovan, B. T. (1967) Existence of a luteolytic hormone in the uterus of the guinea pig. In: Reproduction in the Female Mammal. Eds. G. E. Lamming and E. G. Amoroso. Butterworths, London.

Dumont, A. E. (1965) Fibroplasia: a sequel to lymphocyte exudation. In: The Inflammatory Process, p. 536. Eds. B. W. Zweifach, L. Grant and R. T. McCluskey. Academic Press, New York City.

Florey, Sir Howard (1962) The influence of drugs on inflammatory processes. In: General Pathology, p. 1050. Ed. Sir Howard Florey. Saunders, Philadelphia.

Ginther, O. J., Mahajan, S. \& Casida, L. E. (1966) Local ovarian effects of an intrauterine device in intact and unilaterally ovariectomized guinea pigs. Proc. Soc. exp. Biol. Med. 123, 775.

Ginther, O. J., Pope, A. L. \& Casida, L. E. (1966) Local effect of an intrauterine plastic coil on the corpus luteum of the ewe. 7. Anim. Sci. 25, 472.

Ginther, O. J., Woody, C. O., Janakiraman, K. \& Gasida, L. E. (1966) Effect of an intra-uterine plastic coil on the oestrus cycle of the heifer. F. Reprod. Fert. 12, 193.

Grafenberg, E. (1931) An intrauterine contraceptive method. In: The Practice of Contraception, p. 43. Eds. Margaret Sanger and Hannah M. Stone. Williams \& Wilkins, Baltimore.

Greenwald, G. S. (1965) Interruption of pregnancy in the rat by a uterine suture. 7. Reprod. Fert. 9, 9.

Hansel, W. (1966) Uterine irritants can cause short heat cycles. Hoard's Dairym. 111, 445.

HANSEL, W. \& WAGNER, W. C. (1960) Luteal inhibition in the bovine as a result of oxytocin injections, uterine dilatation, and intra-uterine infusions of seminal and preputial fluids. F. Dairy Sci. 43, 796.

$\mathrm{H}_{\mathrm{AWK}}, \mathrm{H}$. W. (1967) Investigations into the anti-fertility effect of intra-uterine devices in the ewe. $\mathcal{F}$. Reprod. Fert. 14, 49.

Hawk, H. W., Conley, H. H., Brinsfield, T. H. \& Righter, H. F. (1964) Contraceptive effect of plastic devices in cattle uteri. In: Intrauterine Contraception, Proc. 2nd int. Congr., p. 189. Excerpta Medica Foundation, New York City.

Hooker, C. W. \& Forbes, T. R. (1947) Bioassay for minute amounts of progesterone. Endocrinology, 41, 158.

Inskeep, E. K., Oloufa, M. M., Howland, B. E., Pope, A. L. \& Gasida, L. E. (1962) Effect of experimental uterine distention on estrual cycle lengths in ewes. F. Anim. Sci. 21, 331.

Israel, R. \& Davis, H. J. (1966) Intrauterine contraception and the endometrium. F. Am. med. Ass. $195,764$.

Janakiraman, K., Shykla, K. P., Gadgil, B. A. \& Buch, N. C. (1966) Effect of intra-uterine spirals and hormones on uterine histology of the ovariectomized goat. F. Reprod. Fert. 11, 145.

Kar, A. B., Goswami, A., KamboJ, V. P. \& Ghowdhury, S. R. (1964) Effect of a foreign body on the response of the uterus of ovariectomized rats to estrogen. Steroids, 4, 159.

LEDGER, W. J. \& BiCKLEY, J. E. (1966) Effect of plastic IUD on genital tract of rabbits. Obstet. Gynec. 27, 658.

Marcus, S. L. (1965) Influence of ovarian hormones on the leukocytic response to spermatozoa in the uterus of the golden hamster. Fert. Steril. 17, 212. 
Nalbandov, A. V., Moore, W. W. \& Norton, H. W. (1955) Further studies on the neurogenic control of the estrous cycle by uterine distention. Endocrinology, 56, 225.

ParR, E. L. \& SEgaL, S. J. (1966) The effect of an intrauterine contraceptive device on the weight of the rat uterus. Fert. Steril. 17, 648.

ParR, E. L., Schaedler, R. W. \& Hirsch, J. G. (1967) The relationship of polymorphonuclear leukocytes to infertility in uteri containing foreign bodies. F. $\exp$. Med. 126, 523.

Pincus, G. W. (1964) Discussion on Mechanism of contraceptive action. In: Intrauterine Contraception, Proc. 2nd int. Congr., p. 211. Excerpta Medica Foundation, New York City.

WiLson, J. (1963) The nature of the RNA response to estradiol administration by the uterus of the rat. Proc. natn. Acad. Sci. 50, 93.

Yamauchi, M. \& NaKahara, T. (1958) Effects of uterine distention on the estrous cycle of cattle. Fap. J. Anim. Reprod. 3, 121.

Yamauchi, M., Nakahara, T., Kaneda, Y. \& InUI, S. (1967) Effects of uterine distension on the oestrous cycle of the cow. F. Reprod. Fert. 13, 379. 